\title{
Canção, ensino e aprendizagem histórica
}

\author{
Song, teaching and Historical learning
}

Luciano de Azambuja*

\section{Resumo}

O objetivo deste artigo é partilhar alguns dos resultados de uma investigação acerca das protonarrativas escritas por jovens alunos brasileiros e portugueses com base em leituras e escutas de uma canção popular advinda dos seus gostos musicais. Os conceitos estruturantes do quadro teórico foram articulados sobre os referenciais de Rüsen (2001; 2007a; 2007b; 2012); Barca; Schmidt (2009); Marx (2002; 2012); Heller (2008); Forquin (1993); Snyders (1988); Dubet (1994) e Zumthor (1997), entre outros. A metodologia da pesquisa procurou sintetizar as perspectivas dos métodos da pesquisa histórica, métodos de pesquisa em aprendizagem histórica, mediados pelos pressupostos da pesquisa qualitativa etnográfica (Flick, 2004). Os resultados inferidos indicaram que a escritura de protonarrativas da canção pode mobilizar as temporalidades, competências e dimensões da consciência histórica, configurando um ponto de partida significativo de processos de ensino e aprendizagem histórica de jovens alunos.

Palavras-chave: canção popular; jovens alunos; ensino e aprendizagem histórica.

\section{Abstract}

The purpose of this article is to share part of the results of an investigation about the protonarratives written by young Brazilian and Portuguese students from the readings and tapping of a popular song derived from their musical tastes. The structuring concepts of the theoretical framework were articulated from the references of Rüsen (2001; 2007a; 2007b; 2012); Barca; Schmidt (2009); Marx (2002; 2012); Heller (2008); Forquin (1993); Snyders (1988); Dubet (1994); Zumthor (1997), among other authors. The research methodology sought to synthesize the perspectives of methods of historical research, methods of research in historical learning, mediated by the presuppositions of qualitative ethnographic research (Flick, 2004). The inferred results indicated that the protonarrative writing of the song could mobilize the temporalities, competences and dimensions of the historical consciousness, configuring a significant starting point of teaching processes and historical learning of young high school students. Keywords: popular song; young students; History teaching and learning.

\footnotetext{
* Doutor em Educação, Cultura Escola e Ensino, Universidade Federal do Paraná (UFPR). Professor do Instituto Federal de Educação, Ciência e Tecnologia de Santa Catarina (IFSC). Florianópolis, SC, Brasil. lucianodeazambuja@gmail.com
} 


\section{INTRODUÇÃO, PERSPECTIVAS TEÓRICAS E METODOLÓGICAS}

A motivação deste artigo é partilhar alguns dos resultados da tese de doutoramento em Educação defendida em 2013. Na tripla perspectiva da educação histórica, da cognição histórica situada e da didática da história, o objeto da tese consistiu na investigação das protonarrativas escritas por jovens alunos brasileiros e portugueses, com base nas leituras e escutas de uma fonte canção advinda dos seus gostos musicais, mediada por critérios de seleção e de uma pergunta histórica formulada pelo professor-pesquisador, e da subjacente constituição da consciência histórica enraizada na vida prática cotidiana.

Educação Histórica constitui o campo de pesquisa que tem como objeto privilegiado a investigação da consciência histórica de sujeitos e artefatos da cultura histórica em situações de ensino e aprendizagem histórica. Circunscrita nesse campo de pesquisa da consciência histórica, a cognição histórica situada (Barca; Schmidt, 2009) consiste na efetiva aprendizagem histórica situada nos fundamentos epistemológicos da ciência da história e nas situações concretas em que sujeitos específicos estabelecem relações de ensino e aprendizagem histórica, em outras palavras, é a aprendizagem histórica situada na ciência da história e na situação de aprendizagem histórica. E o terceiro vértice dessa tríade teórica, a didática da história, disciplina científica relativamente autônoma à ciência da história que tem como objeto a aprendizagem histórica como processo de formação da consciência histórica, e a consciência histórica como processo de aprendizagem (Rüsen, 2007b, 2012). Em suma, didática da história é a ciência da aprendizagem da consciência histórica.

Os sujeitos da investigação foram jovens alunos brasileiros e portugueses do $2^{\circ}$ ano do ensino médio de escolas públicas das cidades de Florianópolis, Brasil, e Vila Nova de Famalicão, Portugal. Com os desdobramentos do objeto, aplicaram-se os instrumentos de investigação do estudo principal: Narrativas de Vida; Gostos Musicais \& Aulas de História; Aula-Audição; e as Protonarrativas da Canção. Os conceitos e categorias que configuram o quadro teórico foram articulados sobre os referenciais de Rüsen (2001; 2007a; 2007b; 2012); Barca; Schmidt (2009); Martins (2011); Marx (2012); Heller (2008); Forquin (1993); Snyders (1988); Dubet (1996), Dias (2000) e Zumthor (1997), dentre outros autores específicos dos estudos da canção popular. A metodologia da pesquisa empírica procurou sintetizar as perspectivas dos métodos da pesquisa histórica, 
métodos de pesquisa em ensino e aprendizagem histórica, mediados pelos pressupostos da pesquisa qualitativa de natureza narrativística, descritiva e etnográfica (Flick, 2004).

Procuramos fundamentar teórica e empiricamente a presença e significado da canção popular na vida prática cotidiana, nos processos de escolarização, e na constituição das múltiplas culturas e identidades juvenis; pudemos comprovar, qualitativamente, que a escritura de protonarrativas, com base nas leituras e escutas de uma fonte canção advinda dos gostos musicais dos alunos, pode dinamizar as temporalidades, competências e dimensões da consciência histórica de jovens alunos do ensino médio, constituindo ponto de partida motivador para processos significativos de ensino e aprendizagem histórica, com vistas à formação escolar da consciência histórica. Esse percurso propiciou também que pudéssemos sinalizar perspectivas metodológicas de ensino de história e princípios epistemológicos de aprendizagem histórica a partir do trabalho com a canção popular.

Os efeitos, funções e aplicações do conhecimento histórico resultante dessa investigação puderam convergir como indicação de possibilidades de efetivação de uma literacia histórica, um letramento específico de professores e alunos que alfabetize para o trato metódico adequado à especificidade e complexidade da canção popular como fonte para o ensino e aprendizagem histórica. A título de síntese geral dos resultados obtidos com essa pesquisa histórica qualitativa em ensino e aprendizagem histórica, prognosticamos algumas perspectivas-princípios sobre o ensino e aprendizagem histórica a partir do trabalho com a canção popular.

ENSINO E APRENDIZAGEM HISTÓRICA A PARTIR DA CANÇÃO POPULAR

Segundo Rüsen, não basta ter uma teoria de aprendizagem orientadora de estratégias ou metas de aprendizagem, pois somente "valem na medida em que elas podem orientar o agir que envolve a formação da consciência histórica. Um protótipo deste agir é o ensino de história em processos de aprendizagem organizados" (Rüsen, 2012, p.110). Uma das possibilidades anunciadas pelo diálogo entre a teoria rüseniana da aprendizagem histórica e o percurso metodológico construído na pesquisa empírica foi a sistematização de uma perspectiva metodológica para ensinar história com base na canção popular e 
que denominamos de perspectivas metodológicas de ensino, no sentido de uma "pragmática da aprendizagem histórica" (Rüsen, 2012) que constitui a orientação normativa dos processos de ensino e aprendizagem histórica. Os instrumentos de investigação, Narrativas de vida, Gostos musicais e Aulas de História, e Aula-Audição, podem ser circunscritos no campo das estratégias metodológicas de ensino.

A mesma relação entre teoria da consciência histórica e a empiria da pesquisa em ensino de história evidenciou alguns princípios organizadores do pensamento histórico dos jovens alunos com base nas leituras, escutas, escrituras e oralizações acerca da canção popular. Denominamos esses elementos de princípios epistemológicos da aprendizagem histórica a partir da canção popular. Esses princípios são constituídos pelas categorias epistemológicas pertinentes à formação da consciência histórica e foram expressos e evidenciados nas escrituras das protonarrativas da canção: "que ideias de passado, presente e futuro são expressas na canção?”. Evidenciaram-se nos enunciados linguísticos expressos nas narrativas escritas as competências, dimensões e temporalidades da consciência histórica: competência cognitiva, estética e política de interpretação, atribuição de significado, e orientação, constituição de sentido, das experiências humanas no tempo.

Nessa relação teoria-empiria, as fontes narrativas relacionadas à vida prática cotidiana, culturas juvenis e cultura histórica primeira (narrativas de vida, narrativas semiestruturadas acerca dos gostos musicais e dos usos da música em aulas de história, assim como narrativas orais de defesa das músicas escolhidas nas aulas-audição) remetem às perspectivas metodológicas de ensino de história; as protonarrativas da canção, ideias de passado, presente e futuro expressos e evocados na canção, dizem respeito à especificidade dos princípios epistemológicos de aprendizagem histórica, relacionados a pressupostos e condições antropologicamente universais da teoria da consciência histórica. Feita essa sistematização para fins de análise, em contrapartida partimos da hipótese de que não há perspectiva metodológica sem princípio epistemológico, e que não há princípio epistemológico sem uma perspectiva metodológica, enfim, não há método sem teoria e não há teoria sem método, logo, nesta leitura dialética, todos os instrumentos de investigação estão atravessados substancialmente por perspectivas metodológicas e princípios epistemológicos intrinsecamente relacionados de forma autônoma e interdependente. 
Apesar da opção de aplicar os instrumentos de investigação do estudo principal em duas situações e países diferentes, e que, em decorrência dessa escolha, o cotejamento e comparações das experiências foram inevitáveis, partimos da premissa de que a expectativa primeira não é comparar, mas diagnosticar na perspectiva de que cada caso é uma situação e cada situação é um caso, o que nos afasta de qualquer pretensão prescritiva. Todavia, apesar de reconhecer a relativa autonomia e particularidade de cada caso, nossa intenção foi cotejar e articular os casos português e brasileiro na expectativa de delinear, com base nos instrumentos de investigação, perspectivas metodológicas e princípios epistemológicos para o ensino e aprendizagem histórica a partir do trabalho com a canção popular no campo da Educação Histórica.

\section{NARRATIVAS DE VIDA}

Toda e qualquer turma de jovens alunos com que depara um professor-pesquisador constitui um perfil identitário particular, específico e único que pode ser levado em conta como ponto de partida para o trabalho com a canção popular nas aulas de história. Narrativa de vida é uma autobiografia escrita cuja finalidade é fornecer dados, informações e fatos para delinear o perfil identitário da amostra dos sujeitos escolares em situação de ensino e aprendizagem. As narrativas de vida são interpretações e orientações das experiências de vida de um sujeito histórico na sucessão do tempo, portanto, podem dinamizar as competências experiencial, interpretativa e orientacional, e as dimensões cognitiva, estética e política da consciência histórica originária e da identidade histórica primeira dos jovens alunos enraizada na vida prática cotidiana: familiar, escolar e juvenil. Pode-se solicitar aos alunos "Escreva uma narrativa sobre a sua própria história de vida a partir da seguinte sugestão de roteiro" como estímulo para a escritura de narrativas, desde que sejam justificados seus objetivos: título; nome completo, data e local de nascimento; nome completo, ascendência étnica, idade, escolarização e profissão dos pais; vida familiar; vida escolar; vida profissional; fatos marcantes; o que gosta de fazer; $e$ projetos futuros.

Algumas diferenças e afastamentos foram evidenciados entre os casos português e brasileiro, pois as muitas semelhanças e aproximações permitiram abordar genericamente os casos particulares e assim identificarmos as linhas 
mestras de interpretação histórica do estudo principal da investigação. A primeira diferença consiste nas amostras dos jovens alunos pesquisados, embora o perfil identitário seja relativamente semelhante. A amostra dos sujeitos portugueses foi constituída em média por 25 jovens alunos de uma turma do $11^{\circ}$ ano do curso de Línguas e Humanidades de uma Escola Secundária Portuguesa, localizada em Vila Nova de Famalicão, norte de Portugal. Trata-se de uma moderna e bem equipada escola pública de ensino secundário que oferece cursos nas áreas humanas, tecnológicas e profissionalizantes, destinada a socializar e preparar para o "mundo do trabalho" os jovens daquele município. A amostra dos sujeitos brasileiros foi constituída em média por 21 alunos e alunas de uma turma do $2^{\circ}$ ano do curso Técnico Integrado em Saneamento de uma Escola Técnica Brasileira, localizada no centro de Florianópolis, capital do estado de Santa Catarina, sul do Brasil. Trata-se de uma escola federal moderna e bem equipada, especializada em educação profissional e tecnológica voltada para formação e qualificação profissional e cidadã dos indivíduos.

Traçadas as diferenças e afastamentos entre os casos português e brasileiro, pudemos subsumir as particularidades em um caso genérico que sintetiza os casos português e brasileiro em função das aproximações e semelhanças, com o cotejamento das regularidades observadas e o destaque aos eventuais desvios verificados. A primeira forma de identificação é geracional: trata-se de jovens nascidos em sua maioria no ano de 1995 nas cidades onde se localizam as respectivas escolas e em cidades próximas. A média de idade dos pais dos jovens alunos é de 45 anos, portanto, nascidos em torno do ano de 1968. A ascendência étnica dos pais dos jovens alunos portugueses é majoritariamente portuguesa, e dos pais dos jovens brasileiros é portuguesa, alemã, italiana, "afrodescendente" e "ameríndia". Os pais dos jovens alunos portugueses são trabalhadores assalariados da construção civil, indústria têxtil e setores de serviços e comércio, e alguns estão desempregados; trabalhadores com pouca formação escolar e baixa qualificação técnica. Os pais dos jovens alunos brasileiros são trabalhadores assalariados da construção civil, indústria e serviços, entretanto identificamos profissões tais como "agrônomo", "professora" e "arquiteta”, que pressupõem, por sua vez, uma maior formação escolarizada, até mesmo com indicação de realização de curso superior. As narrativas de vida permitem identificar a condição de classe, vida profissional, formação escolar e qualificação técnica dos pais dos jovens alunos, enfim, vida prática 
familiar, e assim estabelecer uma melhor relação entre as condições objetivas da vida prática e as correlatas intencionalidades subjetivas dos sujeitos no universo escolar.

Em relação à vida prática familiar, os jovens alunos brasileiros e portugueses fazem parte de famílias nucleares constituídas de pai, mãe, uma média de dois irmãos e eventuais agregados familiares. Em linhas gerais, metade das amostras dos jovens relataram ter uma "boa relação familiar"; metade das amostras de jovens alunos brasileiros e portugueses manifestou a existência de "conflitos familiares", a alternância de momentos "bons" e "ruins" normais em qualquer família. Em relação à vida escolar dos jovens pesquisados, adentramos uma área de interesse especial para a investigação: a vida prática escolar e as subjacentes, cultura escolar e cultura da escola. Em ambos os casos, podemos observar a construção das imagens ideais do "bom aluno" e os estereótipos autodepreciativos dos alunos identificados com a imagem do "mau aluno"; constatamos que os alunos se identificam mais com a cultura da escola, com a instituição escolar em si, pelas oportunidades que ela proporciona, do que com a cultura escolar propriamente dita. No caso português, houve maior incidência de alunos que se autoidentificaram como "bons alunos" e que deram maior destaque aos "relacionamentos humanos" e afetivos estabelecidos no ambiente escolar, se comparados aos alunos brasileiros. No que diz respeito à vida prática profissional, verificamos que as amostras não são constituídas de jovens alunos trabalhadores, portanto, não possuem uma vida prática produtiva, apesar de que no caso brasileiro, um terço da amostra relatou que trabalha, faz estágio e é bolsista da escola em questão.

Em relação aos fatos marcantes, o tópico remete à rememoração da experiência do passado; reporta às recordações do passado operacionalizadas e aos subjacentes significados e sentidos, positivos e negativos, valorativa e afetivamente atribuídos às experiências do passado. Em suma, os fatos marcantes das narrativas de vida dos jovens alunos brasileiros e portugueses estão diretamente relacionados à vida prática cotidiana: os "bons" e "maus" momentos da vida prática familiar e escolar, e as subjacentes relações de coleguismo e amizade dos grupos juvenis que se dão no entre-lugar da família e da escola, ou seja, as experiências significativas positivas ou negativas rememoradas como acontecimentos relevantes na vida dos jovens alunos se dão efetivamente nos espaços da experiência da vida prática familiar, escolar e juvenil. 
“O que gosta de fazer” remete à capacidade de interpretação do presente; diz respeito às experiências rememoradas, significados atribuídos e sentidos constituídos na vida prática atual e que engendram, por sua vez, a constituição das múltiplas culturas e identidades juvenis. Os enunciados linguísticos do tópico "o que gosta de fazer" constituem evidências das manifestações das dimensões cognitiva, estética e política da cultura de massa mediatizada pelas múltiplas culturas juvenis, e do reverso processo assimétrico e desproporcional de juvenilização da sociedade e da própria cultura de massa. Dois terços dos jovens alunos portugueses da amostra fizeram referência aos esportes em diversas modalidades; em ordem decrescente de incidências, os jovens gostam de ouvir música, estar com os amigos, sair, passear e se divertir; buscam satisfação navegando na internet e nas redes sociais em boa parte do seu tempo. Alunos e alunas gostam de namorar, abraçar e beijar; gostam de dançar, ler e ver filmes na televisão e no cinema; apreciam comer, estar com a família, viajar e ir à praia. Jovens alunas e alunos portugueses sentem prazer em comprar, ir ao teatro, rir, dormir, conhecer novas pessoas e escrever, além de uma diversidade de gostos, hobbies e prazeres individuais como fotografia, "ouvir o mar" e estar feliz. Já os jovens alunos brasileiros gostam de praticar esporte, ouvir música, ler, escrever, ver filmes, "sair e divertir-se", "estar com amigos" e "ir à praia".

Partindo da tripla perspectiva das três intenções originárias humanas intelecto, sentimento e vontade - é que podemos verificar no tópico "o que gosta de fazer" o predomínio inconteste da dimensão estética, subjetiva e identitária que configura a interpretação do presente das culturas juvenis. O que os jovens alunos brasileiros e portugueses gostam de fazer, ou seja, aquilo que lhes dá prazer e satisfação, as coisas pelas quais eles se identificam, o que tem significado, importância e relevância para eles, enfim, o que lhes diz respeito está relacionado predominantemente às dimensões estéticas, emocionais e subjetivas das culturas juvenis mediadas pela cultura de massa. As dimensões predominantemente estética, emocional e identitária das culturas juvenis mediadas pela cultura de massa constituem a interpretação estética do presente que diz respeito à constituição das múltiplas identidades juvenis. Seus gostos são enraizados e advêm das respectivas condições objetivas das suas vidas práticas cotidianas, familiares e escolares. Portanto, no espaço da experiência da vida prática juvenil, no vazio interinstitucional deixado pela família e pela escola, e ocupado em todos "cantos" e "lados" pela cultura de massa mediatizada, 
é que os jovens alunos constituem as suas múltiplas culturas juvenis grupais e subjacentes identidades juvenis individuais. Esse predomínio da dimensão estético-emocional na cultura primeira dos jovens alunos é que confere à operação da consciência originária a marca de uma interpretação estética do presente.

Os projetos futuros dos jovens dizem respeito à orientação do futuro, aos horizontes de expectativa dos jovens e seus prognósticos de curto, médio e longo prazo. Em ambos os casos, o principal projeto de futuro consiste na continuidade e prolongamento dos estudos com vistas à realização e conclusão de um curso superior relacionado às respectivas áreas dos cursos secundário e técnico realizados; outro ponto em comum são as projeções de emprego e carreira e de realização de viagens a outros países para conhecer novas culturas. Em relação às diferenças, identificamos no caso brasileiro a intenção manifestada por alguns jovens de continuidade e prolongamento dos estudos para além da graduação, perspectivando realizar curso de mestrado, doutorado e pós-doutorado; já em relação ao caso português, observamos algumas referências a projetos relacionados a trabalho social e político, além de expectativas associadas à realização pessoal e subjetiva. Todos esses exemplos de projetos futuros dos jovens alunos portugueses e brasileiros remetem à categoria vida prática produtiva, o trabalho. Em suma, os projetos futuros dos jovens alunos e alunas estão diretamente relacionados e parecem vislumbrar a reprodução, continuidade e possibilidade de ascensão social das atuais condições objetivas das respectivas vidas práticas escolar, produtiva e familiar, como partes orgânicas constitutivas da vida prática cotidiana. $\mathrm{O}$ projeto de futuro da maior parte dos jovens alunos brasileiros e portugueses é tornarem-se os "herdeiros", o adulto ideal, o cidadão consumidor. Na instância de verificação da vida prática social, no entanto, esses ideais não correspondem ao fenômeno observável das múltiplas modalidades de transição da juventude para a vida adulta da sociedade contemporânea. Essas formas de transição para a vida adulta problematizam a delimitação das fronteiras temporais da juventude: imprecisão, indefinição e diversidade que nos impelem a pensar não em juventude, mas sim em juventudes como uma condição juvenil. As determinações geracional, classista, étnica e de gênero acabam por condicionar a constituição das múltiplas identidades juvenis e os respectivos projetos futuros de transição para a vida adulta ideal, segundo determinadas concepções de sociedade. 


\section{Gostos musicais E AUlas de História}

O que é música? Música é a arte humana da combinação, sucessão e simultaneidade de sons e sentidos em seus três elementos fundamentais: harmonia, melodia e ritmo, coloridos substancialmente pelo timbre. A música é muito importante, presente e parte fundamental na vida prática cotidiana dos jovens alunos. A música pode dinamizar as competências da experiência do passado, interpretação do presente e orientação do futuro, bem como as respectivas dimensões cognitiva, estética e política da consciência juvenil primeira dos jovens alunos. A música estetiza a vida; contrapõe, extrapola e transcende o princípio da realidade da vontade de verdade da ciência e a vontade de poder da política, e instaura o princípio do prazer da vontade de beleza da arte. A música constitui elemento indispensável nas práticas de entretenimento, lazer e diversão, constitutivos das múltiplas culturas e identidades juvenis no duplo processo de socialização da juventude e juvenilização da sociedade. Pudemos constatar que os jovens brasileiros e portugueses gostam de fazer coisas diretamente relacionadas às dimensões estéticas, emocionais e intersubjetivas das culturas juvenis mediatizadas pela cultura de massa e que esse predomínio da dimensão estética e emocional na cultura primeira dos jovens alunos é que confere à operação da consciência originária a marca de uma interpretação estética do presente. Nessa interpretação estética da vida prática presente a música ocupa o centro dos interesses constitutivos das identidades juvenis. Do ponto de vista mais abrangente e abarcante da vida prática cotidiana, representada nas narrativas de vida, e que engloba vida prática familiar, escolar e juvenil, é justamente no enfoque desta última que foi possível afunilar em direção a uma delimitação mais específica da relevância da música da vida prática dos jovens, como um ponto de partida para uma metodologia do ensino de história a partir da canção popular. Apresentamos na sequência a síntese das respostas escritas na forma de narrativas semiestruturadas do instrumento de investigação Gostos musicais \& Aulas de História, acerca dos significados da música na vida prática cotidiana, os gostos musicais e os conteúdos, justificativas, finalidades e métodos dos usos da música em aulas de história, segundo a concepção dos jovens alunos brasileiros e portugueses. 


\section{"Qual o significado da música na sua vida prática?"}

Apesar de uma previsível diferença nas incidências de proporcionalidades das amostras, os enunciados linguísticos das respostas que se referem aos significados, gostos e concepções de usos da música em aulas de história foram muito semelhantes nos casos português e brasileiro. Pudemos verificar pela incidência de referências que a música é muito importante, é parte fundamental e está muito presente na vida prática cotidiana dos jovens, totalidade concreta que articula os espaços da experiência da vida prática familiar, escolar e juvenil. Segundo um jovem português, “Todos os dias ouço música ... a música está sempre presente na minha vida ... Penso que ninguém passa um dia sem ouvir música, ela está presente em qualquer canto". Já um jovem brasileiro, em relação ao mesmo aspecto, atestou: "A música faz parte do nosso dia a dia". Traduzindo perspectivamente, a música está presente na vida prática cotidiana dos jovens alunos, constituída pela interseção dos espaços da experiência da vida prática familiar, escolar e juvenil. Diversas referências feitas pelos alunos atestam a presença da música na vida prática juvenil: “Tenho músicas no telemóvel e posso ouvir em todo o lado: no rádio, na televisão etc., há sempre música", afirmou o jovem português; já a aluna brasileira manifestou as situações e momentos em que a música se faz presente em sua vida prática cotidiana: "Eu começo o meu dia com a música, canta no meu despertador a Carla Bruni. No ônibus, buscar pelo Ipod já virou rotina”.

$\mathrm{Na}$ perspectiva da investigação, as três dimensões da cultura histórica, portanto, da consciência histórica, são igualmente originárias e não podem ser subsumidas umas às outras, pois são partes constitutivas de um complexo de complexos, de uma totalidade abstrata e concreta que tece a teia da constituição científica, artística e política de sentido histórico para a orientação da vida prática atual. Nessa perspectiva, podemos concluir que a música mobiliza as dimensões estética, cognitiva e política da cultura primeira enraizada na vida prática cotidiana dos jovens alunos brasileiros e portugueses. Sentimento, intelecto e vontade, linguagem, consciência e existência, e na perspectiva da investigação, as dimensões estética, cognitiva e política constituem as três dimensões ancestrais da cultura humana, empiricamente verificáveis nas narrativas escritas pelos jovens alunos brasileiros e portugueses acerca dos significados da música na sua vida prática, pois, segundo eles, é possível "expressar suas vontades, sentimentos ou ideias escrevendo uma música”, diz o jovem brasileiro; 
"a música transmite-nos imensas ideias, estados de espírito, emoções", confirma o aluno português.

"Quais são os seus gostos musicais: gêneros, cantores, compositores, grupos e bandas?"

Esta pergunta teve a intenção de investigar os gostos musicais dos jovens alunos como ponto de partida significativo para a aprendizagem histórica com base na canção popular. Intencionou também comprovar empiricamente na pesquisa qualitativa o pressuposto de que, para os jovens alunos portugueses e brasileiros, "música" refere-se especificamente à forma "canção", ou seja, letra e música mediatizada, canção popular fonográfica. Nessa linha de raciocínio, o tópico nos remete à reflexão teórica sobre a influência da cultura de massa da indústria cultural na formação dos gostos musicais dos jovens e na subjacente constituição das múltiplas culturas e identidades juvenis, e no refluxo assimétrico, aleatório e espontâneo da influência dos gostos musicais e das culturas juvenis sobre a cultura de massa da indústria fonográfica cultural. Os gêneros musicais de preferência dos jovens alunos com média de idade em torno dos 17 anos são predominantemente o rock em primeiro lugar isolado, seguido do pop, rap e reggae, gêneros musicais característicos da canção pop anglo-americana veiculada pelas matrizes das corporações transnacionais do disco. Todavia, os jovens também apreciam gêneros cancionais enraizados nas culturas originárias de seus respectivos países e nas apropriações dos gêneros musicais da canção pop anglo-americana. Os cantores, compositores, grupos e bandas de preferência dos jovens são os astros da música pop internacional e os respectivos ídolos nacionais diretamente associados aos gêneros musicais ofertados pela indústria fonográfica cultural monopolizada pelas corporações transnacionais do disco; instaladas nos países periféricos no processo de globalização cultural, ao mesmo tempo em que veiculam os produtos musicais das matrizes metropolitanas, a indústria fonográfica se apropria da criação e produção musical local para satisfazer segmentos do mercado fonográfico que se identificam com a música de tradição nacional, regional e as traduções híbridas de gêneros musicais estrangeiros. 


\section{"Você acha que a música pode ser usada em aulas de História? Que músicas? Por quê? Para quê? Como?”}

Trata-se da terceira e última pergunta desdobrada em cinco questões acerca dos gostos musicais \& aulas de história. Na perspectiva focada na aprendizagem do aluno, as quatro questões fundamentais da didática da história foram adequadas à especificidade e complexidade dos usos da música em aulas de história e formuladas aos sujeitos da pesquisa.

Toda e qualquer música pode ser apropriada como fonte histórica para a aprendizagem histórica, pois tudo que traz a marca da intencionalidade da ação humana no tempo é evidência potencial. Depende do critério histórico de seleção da canção de trabalho, da pergunta histórica formulada que se pretenda orientar a responder, e do grau de adesão que se queira alcançar junto a determinado perfil de jovens alunos em situações concretas de ensino e aprendizagem histórica. Todavia, sugerimos como ponto de partida para o trabalho com música na aula de história, apropriar inicialmente uma fonte canção advinda dos gostos musicais dos jovens, ou seja, letra e música mediatizada que tematiza "história" em seus múltiplos significados. Segundo suas proposições de conteúdos, justificativas, finalidades e métodos dos usos da música em aulas de história, os jovens alunos portugueses e brasileiros tendem a conceber progressivamente a música como artefato estético, recurso didático e fonte histórica. A música emerge espontaneamente da cultura histórica primeira dos jovens alunos mantendo a sua função original enquanto artefato estético da cultura de massa da indústria fonográfica destinado às atividades de entretenimento, lazer e diversão e cuja finalidade é gerar o prazer estético-emocional. Nessa concepção, a justificativa e a finalidade do uso da música se confundem e se reduzem a tornar as aulas de história mais divertidas, descontraídas e dinâmicas; nesse caso específico, a dimensão estética torna-se um fim em si mesma e instrumentaliza as dimensões cognitiva e política, correndo o perigo de efetivar-se uma estetização do histórico que rompe o vínculo com a experiência histórica que possibilita a interpretação fundamentada do presente e a expectativa orientada do futuro. A música concebida como recurso didático instrumentaliza a sua dimensão estética para servir como mero veículo de transporte e artifício artístico que conduz até a dimensão cognitiva e política do conteúdo histórico curricular. Nesse caso, as dimensões cognitivas e políticas da cultura histórica escolar tendem a instrumentalizar a dimensão estética, destituindo-a 
de seu papel ativo na constituição histórica de sentido, podendo provocar uma conteudização do estético, cujos exemplos potencializados são as paródias e as canções didáticas.

Na perspectiva da investigação acerca da aprendizagem histórica com base na canção popular, adotamos como ponto de partida e reafirmamos ao longo do trabalho os seguintes pressupostos prospectivos: o que ensinar, ou seja, o conteúdo consiste nos conceitos históricos substantivos, categorias históricas epistemológicas, categorias históricas gerais, inferidas nas letras e músicas das canções apropriadas; o como ensinar, ou seja, a metodologia do ensino de história consiste nos processos de aprendizagem histórica a partir das leituras, escutas, falas e escrituras de protonarrativas com vistas à escritura de narrativas históricas da canção, ou seja, aprendizagem histórica baseada na leitura histórica da canção; o porquê, ou seja, a justificativa do uso da canção no ensino e aprendizagem histórica reside na premissa epistemológica de que a canção popular pode ser apropriada como fonte histórica para a aprendizagem histórica de jovens alunos, pois como artefato humano constitui evidência potencial; e por fim, o para quê, ou seja, a finalidade do uso da música em aulas de história coincide com a finalidade primeira e última do ensino e aprendizagem histórica na perspectiva da didática da histórica: a constituição, formação e progressão da consciência histórica e a subjacente consolidação da identidade histórica juvenil de jovens alunos do ensino médio.

\section{Aula-Audição}

Aula-audição é a tarefa que consiste na escolha, pelos alunos, de uma música dos seus gostos que, segundo a opinião deles, pode ser usada em uma aula de história. As músicas podem ser apresentadas, recepcionadas e defendidas na aula-audição procurando responder a perguntas históricas formuladas pelo professor-pesquisador: "Por que usar essa música em uma aula de História?"; "Para que usar essa música em uma aula de História?". Tendencialmente as escolhas dos jovens alunos corroboram o pressuposto pragmático de que, quando o jovem é solicitado a escolher uma música do seu gosto musical que pode ser usada em uma aula de história, ele tende a escolher especificamente à forma canção popular. 
Quer pelas suas raízes ancestrais, quer pela sua globalização cultural, a canção popular é um produto do trabalho de criação e produção musical humana, é letra e música, é palavra cantada ou canto falado, acompanhados ou não por instrumentos musicais. Canção popular fonográfica constitui uma criação e produção musical característica da cultura ocidental; é um produto da indústria fonográfica cultural, mercadoria estética do capitalismo monopolista do século XX, o século da canção. A canção popular é uma totalidade, uma acoplagem indissociável constituída pelos seguintes complexos: letra, os enunciados linguísticos em suas formas e conteúdos; música, a combinação de sons a partir dos seus três fundamentos - harmonia, melodia e ritmo -, substancialmente coloridos pelo timbre; as subjacentes performances vocal e instrumental; e por fim, o fonograma, o suporte técnico, tecnológico e mercadológico de reprodução de canções. As tarefas da aula-audição têm como intencionalidade possibilitar aos alunos, mediante o trato heurístico, didático e metódico estabelecido diretamente com a fonte canção, a operação da inferência histórica que transmuta a canção popular em fonte histórica subsumindo-a em fonte canção. Os pressupostos estéticos, didáticos e históricos implícitos à aula-audição podem mobilizar uma progressão tendencial da consciência histórica primeira dos jovens alunos no sentido de uma concepção de música enquanto artefato estético e recurso didático, para uma concepção de música como fonte histórica para a aprendizagem histórica. A mediação do professor-pesquisador na seleção da canção de trabalho dentre as mais votadas pelos alunos depende das potencialidades didáticas vislumbradas nas canções escolhidas pelos jovens, da pergunta histórica que pretenda formular a fonte canção, dos conceitos históricos substantivos, categorias históricas epistemológicas, categorias históricas gerais e as subjacentes competências específicas da consciência histórica que ambicione mobilizar nos jovens alunos em situação de aprendizagem.

As 13 canções escolhidas, ouvidas e defendidas pelos jovens alunos portugueses foram estas, por ordem de apresentação em duas aulas-audição: Fora da Lei, de Bezegol; Earth Song, de Michael Jackson; Conquistador, de Da Vinci; Imagine, de John Lennon; Viva la Vida, de Cold Play; Wind of Change, de Scorpions; Grândola Vila Morena, de Zeca Afonso; Buffalo Soldier, de Bob Marley; Silver and Gold, do U2; We Are The World, de Michael Jackson; Portugal Sulrreal, de Dealema; Quero liberdade já, de Barrako; e This is War, 
de 30 Second to Mars. As 10 canções escolhidas, ouvidas e defendidas pelos alunos brasileiros foram estas, por ordem de apresentação em duas aulas-audição: Para não dizer que não falei das flores, de Geraldo Vandré; Metrô Linha 743, Raul Seixas; Waiting on the world to change, John Mayer; Geração Coca-Cola, Legião Urbana; Cuando los angeles lloran, Maná; Fábrica, Legião Urbana; Civil Wars, Guns and Roses; Admirável gado novo, Zé Ramalho; Astronauta, Gabriel O Pensador; e Era um garoto que como eu amava os Beatles e os Rolling Stones, Engenheiros do Hawaii.

Significativo e relevante foi o processo de reflexão histórica e epistemológica ao qual os jovens alunos foram estimulados, ainda que de forma inconsciente, em função dos desafios da tarefa da aula-audição. Nessa perspectiva de análise, podemos verificar que algumas músicas escolhidas se aproximaram mais do gosto musical dos alunos, mas não se adequaram tanto ao critério didático histórico, e isso, portanto, influenciou na consistência das defesas das justificativas e finalidades do uso de tais músicas no contexto de uma aula de história. As canções escolhidas e defendidas pelos jovens alunos brasileiros e portugueses nas aulas-audição advieram dos seus respectivos gostos musicais, enfim, dos gêneros, cantores, compositores e grupos de preferência dos jovens, condicionados pela diversidade de escolhas do cardápio ofertado pela indústria fonográfica cultural. Seus cantores e grupos preferidos são os velhos e novos ídolos da cultura de massa da indústria cultural, seguidos dos representantes da canção popular brasileira e portuguesa mais ligada às raízes culturais originárias, e do hibridismo cultural que dialoga e negocia com a cultura dominante para se apropriar de gêneros da canção popular anglo-americana em traduções "abrasileiradas" e "aportuguesadas" de rock, pop, reggae e rap. Após a apresentação, audição e defesa das músicas escolhidas pelos jovens alunos portugueses e brasileiros nos encontros dedicados à aula-audição, foram selecionadas segundo votação pelos alunos e mediação do professor-pesquisador, a seleção da canção de trabalho, ou seja, a fonte canção escolhida para ser objeto de investigação.

Para concluir a análise e interpretação dos resultados obtidos por meio do instrumento de investigação aula-audição, resumimos a análise da música mais votada pelos jovens alunos e selecionada pelo pesquisador como a canção de trabalho da investigação. No caso português selecionamos Fora da Lei, do rapper português contemporâneo Bezegol. Trata-se de uma canção popular 
fonográfica, uma canção pop portuguesa, um rap-reggae português que se apropria crítica e criativamente de gêneros musicais da canção popular anglo-americana da cultura de massa para criar, produzir e divulgar, provavelmente de forma independente e alternativa, ou seja, à margem da grande indústria fonográfica cultural, uma canção híbrida, global e local que se circunscreve na cultura hip-hop de jovens pobres das periferias urbanas das grandes cidades do mundo. Uma canção popular que tematiza em sua letra e música a crise portuguesa da época da investigação: a crise econômica, social, política e cultural da sociedade portuguesa, em suas relações com o passado, que remete à Revolução dos Cravos e à crise portuguesa do tempo presente, "Andam-no a tentar enganar/ aldrabar a roubar, eu sei”, e à falta de perspectivas de futuro, "Será que nos vamos aguentar/ ou virar uns fora da lei?".

E por fim, a escolha da canção Geração Coca-Cola no caso brasileiro. Primeiro, por todos os significados da Legião Urbana e das suas canções sobre os gostos musicais dos jovens alunos brasileiros investigados neste estudo principal e em anteriores. Segundo, porque Geração Coca-Cola, pelo significado da canção no disco de estreia daquela que se tornaria a principal banda do chamado Rock Brasil, e, por consequência, o título da canção passou a designar a geração que foi jovem nos anos 1980 no Brasil e que compôs a trilha sonora e participou ativamente do processo de redemocratização da sociedade brasileira que deságua na atualidade do Brasil contemporâneo. A principal justificativa da seleção de Geração Coca-Cola como canção de trabalho do estudo principal do caso brasileiro é que ela se adapta perfeitamente aos objetivos da investigação: faz parte dos gostos musicais dos jovens alunos, pode ser usada em uma aula de história porque expressa ideias de passado, presente e futuro da sociedade brasileira e que podem configurar ponto de partida significativo para a constituição da consciência histórica e da identidade histórica originárias dos jovens alunos brasileiros com base nas leituras, escutas e escrituras de protonarrativas da canção.

Em síntese geral, a canção popular apropriada como fonte histórica; transmutada pela inferência em fonte canção que tematiza "história" em suas perspectivas conceitual e categorial; a seleção da fonte canção em função da formulação da pergunta histórica que se pretenda responder; toda essa estratégia metodológica resulta na delimitação da canção de trabalho. A seleção da canção de trabalho constitui o ponto de partida e de chegada de um processo 
de ensino e aprendizagem histórica que não está subordinado a nenhum conteúdo histórico predeterminado pelo currículo histórico escolar, ou gênero musical, cantor e grupo de preferência do professor, ou mesmo por se fazer presente como "ilustração" nos livros didáticos de história. Ao contrário, o conceito histórico substantivo, a categoria histórica epistemológica, ou ainda, a categoria histórica geral a ser trabalhada na aula de história emerge da categorização e interpretação histórica das protonarrativas de uma canção de trabalho advinda dos gostos musicais dos alunos, e do subsequente recorte temático estabelecido pelo professor de história, com vistas à formação escolar da consciência histórica originária e da identidade histórica primeira dos jovens alunos em situação de ensino e aprendizagem histórica.

\section{Protonarrativas dA CANÇÃo}

A interpretação é uma resposta a uma pergunta; ela se dá mediante a operação processual que transforma informações, dados e fatos em "histórias": "como ela transforma fatos em histórias, deve ser considerada como a operação de pesquisa própria, especificamente histórica” (Rüsen, 2007a, p.127). A apresentação da resposta histórica, ou seja, a interpretação, já não mais pertence à pesquisa em sua tarefa de extrair as informações empíricas das fontes, mas trata-se da operação que formata historiograficamente os resultados obtidos por meio das fontes. A partir dessa noção de interpretação histórica advinda da pesquisa histórica historiográfica apropriada didaticamente na perspectiva de uma pesquisa histórica qualitativa em ensino e aprendizagem histórica é que buscamos interpretar os dados, informações e fatos extraídos, codificados e categorizados das fontes narrativas protonarrativa da canção.

Protonarrativas da canção são as manifestações empíricas dos enunciados linguísticos da consciência histórica originária de jovens alunos com base nas primeiras leituras e escutas de uma fonte canção advinda dos seus gostos musicais configurados na vida prática cotidiana. Protonarrativas da canção são interpretações da canção a partir da escritura de uma resposta à pergunta histórica formulada à canção; são os primeiros significados e sentidos atribuídos e constituídos sobre a experiência estética de recepção da canção, e a concomitante manifestação empírica dos enunciados linguísticos dessas interpretações e orientações da experiência da canção. 
Selecionada a canção de trabalho, o professor-pesquisador efetivou a aplicação do último e principal instrumento de investigação do estudo principal, as Protonarrativas da canção: "Leia a letra e escute a música da canção de trabalho e escreva uma narrativa histórica procurando responder à seguinte pergunta: Que ideias de passado, presente e futuro são expressas na canção?”.

As condições e circunstâncias objetivas da vida prática atual dos sujeitos condicionam, substanciam e orientam as relações temporais estabelecidas com determinadas ideias-imagens do espaço de experiência e dos horizontes de expectativa dos sujeitos em situação de ensino e aprendizagem histórica. As leituras e escutas da canção de trabalho podem mobilizar a experiência do passado: um passado histórico que infere conceitos históricos substantivos, categorias históricas epistemológicas e categorias históricas gerais; um passado da canção que se limita a interpretar os enunciados primeiros da canção em sua interpretação estética do tempo; e por fim, a inferência lacunar por parte dos jovens de um passado indeterminado e a-histórico que necessita ser historicizado para responder às perguntas constitutivas de um conceito histórico substantivo: o que foi o caso? Quem? A favor de quem? Contra quem? Quando? Onde? Por quê? Para quê? Como? Consequências e efeitos? Significados temporais: passado, presente e futuro?

Emergiram das protonarrativas da canção escritas por jovens alunos portugueses a partir das leituras e escutas da fonte canção Fora da Lei de Bezegol três ideias de passado predominantes. Um passado remoto glorioso marcado por descobrimentos, conquistas e colonizações, e um passado recente de crise que tem como marco divisório a Revolução dos Cravos. Para alguns jovens, que no jogo dos pêndulos tenderam mais para a cultura histórica escolar, a Revolução dos Cravos foi o último feito relevante da história recente contemporânea de Portugal, digna de orgulho e constitutiva da identidade portuguesa. Outros alunos penderam mais para o polo da cultura juvenil primeira e, com as inferências à letra da música, associaram a Revolução dos Cravos às causas e origens dos desmandos, corrupção e incompetência dos políticos que governaram Portugal no período inaugurado pela revolução do "25 de abril de 1974". E por fim, três jovens alunas expressaram uma ideia de passado que denominamos "passado indeterminado", ou seja, um passado genérico, vago e abstrato onde os acontecimentos não são situados no tempo e no espaço e os sujeitos são personagens anônimos e sem rosto, representados sob categorias 
gerais, tais como "poderosos", "pobres", "superiores" e "as pessoas", sem delimitar, definir e situar específica e historicamente:

A Revolução do 25 de Abril veio trazer liberdade ao nosso país e deu-nos direitos que antes não existiam e a partir daí o país começou a melhorar [mas os políticos não souberam controlar e aplicar bem o nosso dinheiro e agora nós é que temos de pagar e eles só sabem fazer discursos e dar más notícias.] (Marília, 16 anos)

Já no caso brasileiro, emergiram das protonarrativas da canção escritas com base nas leituras e escutas da fonte canção Geração Coca-Cola três ideias-imagens de passado predominantes: um passado indeterminado; a influência dos Estados Unidos; e os conceitos históricos substantivos Ditadura Militar Brasileira e Redemocratização, além das categorias históricas gerais, tais como ditadura, revolução e capitalismo. Verificamos que um terço da amostra fez referências a um passado indeterminado: um passado vago, genérico e abstrato perdido no tempo; um passado atípico constituído de sujeitos genéricos, "as pessoas", "os superiores”, “os brasileiros”, cujas ações descontextualizadas de experiências, significados e sentidos, não dizem respeito a processos reais humanos acontecidos na sucessão do tempo, mas sim às inferências atribuídas pelos jovens alunos à canção a partir da sua cultura histórica primeira. Um segundo elemento recorrente nas protonarrativas escritas pelos jovens alunos brasileiros consiste em uma ideia de passado associada à influência dos Estados Unidos sobre o Brasil com base nas inferências feitas ao enunciado da letra da música "Com os enlatados dos USA, de 9 às 6". Observamos inúmeras e diversas referências feitas pelos jovens alunos ao recorte temático que designamos na perspectiva da investigação de Americanização do Brasil. Ainda em relação às ideias de passado, apesar de não haver nenhuma menção direta e explícita nos enunciados da letra da música que remeta a tal, os jovens alunos inferiram e expressaram conceitos históricos substantivos: Ditadura Militar Brasileira; Diretas Já; Segunda Guerra Mundial; Guerra Fria e Revolução Industrial.

$\mathrm{O}$ ano que a música foi lançada também tem grande significado pois foi no final da Ditadura Militar do Brasil, e toda a raiva e revolta do povo estava sendo mostrada publicamente. As ideias que a letra traz, e que o Brasil só importava dos E.U.A, por questões políticas de estado... (Thábata, 17 anos) 
A canção popular pode dinamizar a interpretação do presente. A canção popular, atualizada a cada vez na performance oral mediatizada, não deixa de constituir uma interpretação estética do presente que pode remeter tanto à vida prática atual quanto ao presente da canção que atualiza o passado e se presentifica na audição, recepção e comunicação, mobilizando o leitor-ouvinte, a partir da interpretação estética da canção, a perspectivas de orientação política-identitária na vida prática atual. Em resumo, as ideias de presente inferidas pelos jovens alunos portugueses com as leituras e escutas de Fora da Lei remetem a uma interpretação do presente associada à caracterização da profunda crise econômica, financeira, social, política e cultural da sociedade portuguesa da época da investigação, ou seja, reporta à crise portuguesa recente, portanto uma temática da história do tempo presente. A crise é descrita em seus desdobramentos econômicos, sociais e, sobretudo, políticos, estes últimos responsabilizados majoritariamente pelos jovens alunos como os culpados causadores da crise, embora alguns alunos discordem de certa visão determinista que reduz toda a complexidade causal da crise à política, absolve a "população" de sua parcela de responsabilidade ao vitimizá-la, ou condena-a pela não participação em questões que dizem respeito à sua própria situação e à do país.

Em relação ao presente ele refere que Portugal se encontra numa crise profunda, a população está desesperada, cada vez cortam mais os salários, aumentam os impostos e sobem os preços... (Cláudia, 16 anos)

Podemos identificar nas protonarrativas escritas pelos jovens alunos brasileiros após as leituras e escutas de Geração Coca-cola três ideias de presente a partir da fonte canção: um presente da canção; um presente prático como mudança; e um presente prático enquanto permanência. Um presente da canção que é o agora da vez de a geração coca-cola cuspir de volta o lixo em cima do outro da canção; um presente da canção que também remete ao ano do lançamento do primeiro disco da Legião Urbana, que trazia a música Geração Coca- Cola e que de certa forma anunciava o que estava acontecendo na vida prática concreta: os filhos nascidos durante a vigência do regime militar são as crianças vislumbradas "derrubando reis" e ajudando a acabar com a ditadura no processo denominado redemocratização do Brasil. Por outro lado, manifestou-se também nas protonarrativas um presente prático como mudança, que corresponderia à geração coca-cola da atualidade, a atual geração de jovens do Brasil 
que constitui hoje o futuro, que, a exemplo da geração passada, tem de fazer a sua parte para construir um país melhor e ajudar a combater os "reis" dos dias de hoje e se livrar de todo o lixo que impede a consolidação de uma sociedade mais justa e menos desigual. E por fim, um presente prático enquanto permanência da influência do poder e da cultura da "América do Norte" sobre o Brasil e os brasileiros.

Então em relação ao presente ele reverte esta situação, o compositor deixa claro quando diz "mas agora chegou a nossa vez", "somos os filhos da revolução", ele quer de qualquer forma, reverter a situação em que nosso país passava durante a Ditadura Militar, ele quer ser ouvido, quer deixar claro que tem sua opinião e que sendo jovem ele tem muito poder em suas mãos. (Solange, 18 anos)

A canção de trabalho pode dinamizar a orientação do futuro da consciência histórica originária dos jovens alunos. Um futuro da canção representado pelas condições e circunstâncias da vida prática atual e que se projeta no futuro como continuidade do presente; ou um futuro da canção resultado de um prognóstico feito no passado e que se concretiza no presente e, a partir de então, passa a fazer parte do passado, mas que volta a se presentificar a cada nova performance da canção.

Em relação às ideias de futuro, verificamos que apenas um quinto da amostra de jovens alunos portugueses fez inferências relacionadas à orientação do futuro representada nas protonarrativas da canção portuguesa. O que nos permite concluir inicialmente que a canção Fora da Lei remeteu a grande maioria dos jovens alunos à temporalidade da vida prática atual, ou seja, ao tempo presente, um pouco menos da metade dos jovens reportou à dimensão temporal do passado, e somente um quinto da amostra de jovens alunos fez menção às expectativas de futuro. Segundo as narrativas destes últimos, as ideias de futuro aparecem associadas a uma noção de futuro interditado que aparece como "barreira", um futuro indeterminado, incerto e inseguro que constitui um enigma que só se descobrirá efetivamente no futuro próximo. Alguns alunos têm a expectativa de que as coisas vão piorar ainda mais do que no presente, outros se questionam sobre o futuro, alinhavados com a pergunta da canção, "Será que vamos aguentar ou virar um fora da lei?", e somente uma jovem aluna manifestou uma "visão mais otimista" em relação ao futuro do país. 
No futuro vemos que os preços vão aumentar ainda mais, e que a vida se vai tornar ainda mais difícil do que já é, e pergunta então, como será a nossa próxima geração? Será que se aguenta ou vai tornar-se uns foras da lei? (Carlota, 17 anos)

Em relação às ideias de futuro, os jovens alunos brasileiros manifestaram em suas protonarrativas as interpretações atribuídas às ideias de futuro expressas na canção. Nesse futuro da canção o "amanhã" depende da "população jovem" e esse futuro será completamente diferente do tempo presente; nesse futuro da canção interpretado pelos jovens, as novas gerações darão continuidade às mudanças iniciadas pela geração anterior; as pessoas acordarão para a real situação do país. Os jovens também remeteram a projeções de futuro mais relacionadas à vida prática atual, ou seja, um futuro prático como mudança. Nesse futuro prático o futuro é visto como mudança revolucionária para melhor; a partir da canção, o discernimento do "certo" e do "errado" poderá mudar o futuro e a vida das pessoas:

Mas também diz a música que futuramente, as pessoas abrirão os olhos para o que realmente acontece e o como é a situação no país e então agirão de maneiras diferentes. (Cássia, 16 anos)

\section{CONSIDERAÇÕES FINAIS}

Pudemos corroborar a hipótese de que a escritura de protonarrativas a partir das primeiras leituras e escutas de uma fonte canção advinda dos seus gostos musicais pode mobilizar as dimensões cognitiva, estética e política da consciência histórica originária de jovens alunos do ensino médio e constituir um ponto de partida significativo para processos de ensino e aprendizagem histórica. A experiência cognitiva do passado e os subjacentes conceitos históricos substantivos, categorias histórica epistemológicas, e categorias históricas gerais, bem como ideias-imagens e outros recortes temáticos; a interpretação estética do presente, após a interpretação estética da canção que tematiza implícita ou explicitamente as três dimensões do tempo histórico; e por fim, a orientação política do futuro na constituição das identidades históricas primeiras dos jovens em relação às alteridades dos outros representados na canção ou identificados na vida prática atual. Todas essas competências, dimensões e 
temporalidades da consciência histórica podem tecer o fio condutor que interconecta passado, presente e futuro na constituição histórica de sentido da consciência histórica originária de jovens alunos. Na perspectiva da Educação Histórica, consciência histórica é a competência cognitiva-racional, estético-narrativa, político-identitária, e ainda, ética-moral-religiosa, de interpretação (atribuição de significados) e orientação (constituição de sentidos) da experiência da mudança humana do tempo (tradicional), sobre o tempo (exemplar), contra o tempo (crítica) e no tempo (genética).

Com base nos dados empíricos extraídos das fontes narrativas e interpretados historicamente, tendo como referência o quadro conceitual categorial da investigação, verificamos que os jovens alunos brasileiros e portugueses narrativizaram por escrito ideias de passado, presente e futuro, assim como estabeleceram múltiplas relações temporais entre as três dimensões do tempo histórico, a partir das leituras e escutas de uma fonte canção advinda dos seus gostos musicais. Observamos que as fontes canções mobilizaram as temporalidades do passado, presente e futuro e dinamizaram as competências da experiência, interpretação e orientação da consciência histórica originária dos jovens alunos portugueses e brasileiros manifesta empiricamente nos enunciados linguísticos das protonarrativas da canção. Procuramos demonstrar que a escritura de protonarrativas a partir das leituras e escutas da canção, em resposta a uma pergunta formulada, pode potencializar a rememoração de conteúdos experienciais do passado, a atribuição de significados da interpretação do presente, e a constituição de sentidos da orientação do futuro. Indissociável à totalidade das complexas dimensões e competências da consciência histórica, privilegiamos evidenciar nas protonarrativas da canção a manifestação mesclada, relativamente autônoma e reciprocamente interdependente das três dimensões originárias da consciência humana no tempo: as dimensões cognitiva, estética e política:

Quanto ao futuro a música diz-nos que além das dificuldades atuais temos que seguir em frente e acreditar que o futuro ainda pode ser melhor que o nosso passado e presente. (Isabel, aluna portuguesa, 16 anos)

Como a própria música já diz não seremos controlados como éramos tempos atrás, não seremos lembranças esquecidas; conscientizaremos o presente e mudaremos o futuro. (Ana, aluna brasileira, 16 anos) 
A interpretação histórica das protonarrativas da canção escritas com base nas primeiras leituras e escutas de uma fonte canção advinda dos gostos musicais dos jovens, pode constituir um ponto de partida significativo para múltiplas perspectivas de planejamento de efetivas Aulas de História com base em trabalho metódico com fontes históricas multiperspectivadas e de natureza diversa, com vistas à formação da competência narrativa da consciência histórica de jovens alunos do ensino médio. Eis o horizonte de expectativa desta pesquisa sobre canção, ensino e aprendizagem histórica.

\section{REFERÊNCIAS}

AZAMBUJA, Luciano de. Jovens alunos e aprendizagem histórica: perspectivas a partir da canção popular. Tese (Doutorado em Educação) - Programa de Pós-Graduação em Educação, Universidade Federal do Paraná. Curitiba, 2013.

DIAS, Marcia T. Os donos da voz: indústria fonográfica brasileira e mundialização da cultura. São Paulo: Boitempo, 2000.

DUBET, François. Sociologia da experiência. Lisboa: Instituto Piaget, 1994.

FLICK, Uwe. Uma introdução à pesquisa qualitativa. Trad. Sandra Netz. Porto Alegre: Bookman, 2004.

FORQUIN, Jean-Claude. Escola e cultura: as bases sociais e epistemológicas do conhecimento escolar. Porto Alegre: Artes Médicas Sul, 1993.

HELLER, Agnes. O cotidiano e a história. Trad. Carlos Nelson Coutinho e Leandro Konder. São Paulo: Paz e Terra, 2008.

KOSELLECK, Reinhart. Futuro passado: contribuição à semântica dos tempos históricos. Trad. Wilma Patrícia Maas, Carlos Almeida Pereira; rev. trad. César Benjamim. Rio de Janeiro: Contraponto; Ed. PUC-Rio, 2006.

MEDRANO, Concepción (Coord.) Las historias de vida: implicaciones educativas. Buenos Aires: Alfagrama, 2007.

NETTO, José Paulo. Introdução ao estudo do método de Marx. São Paulo: Expressão Popular, 2011.

(Org.) O leitor de Marx. Rio de Janeiro: Civilização Brasileira, 2012.

PAIS, José M. Culturas juvenis. Lisboa: Imprensa Nacional - Casa da Moeda, 2003.

RÜSEN, Jörn. Razão histórica. Teoria da história: os fundamentos da ciência histórica. Trad. Estevão de Rezende Martins. Brasília: Ed. UnB, 2001.

. Reconstrução do passado. Teoria da história II: os princípios da pesquisa histórica. Trad. Asta-Rose Alcaide. Brasília: Ed. UnB, 2007. 
RÜSEN, Jörn. História viva. Teoria da história: formas e funções do conhecimento histórico. Trad. Estevão de Rezende Martins. Brasília: Ed. UnB, 2007. Aprendizagem histórica: fundamentos e paradigmas. Trad. Peter Horst Rautmann, Caio da Costa Pereira, Daniel Martineschen e Sibele Paulino. Curitiba: W.A. Editores, 2012.

SCHMIDT, Maria A.; BARCA, Isabel (Org.) Aprender história: perspectivas da educação histórica. Ijuí, RS: Ed. Unijuí, 2009.

SNYDERS, Georges. Alegria na escola. São Paulo: Manole, 1988.

TATIT, Luís. O século da canção. Cotia, SP: Ateliê Editorial, 2004.

ZUMTHOR, Paul. Introdução à Poesia Oral. São Paulo: Hucitec, 1997.

Artigo recebido em 30 de novembro de 2016. Aprovado em 4 de fevereiro de 2017. 